\title{
Serial Narrative, Intertextuality, and the Role of Audiences in the Creation of a Franchise: An Analysis of the Indiana Jones Saga from a Cross-Media Perspective
}

\author{
Manuel Hernández-Pérez \\ and Jose Gabriel Ferreras \\ Rodriguez
}

Rather than the simple adaptation of a story across different media, cross- media narrative should be defined as that which is transformed by virtue of use a medium and its different languages (film, comics, video games, etc.). This article extends and updates the dimensions of previous cross-media analysis models by underlining narrative aspects of the different products discussed and examining the influence of generic conventions along the way. To test this methodology, the article focuses on a product from the "adventure" genre- the Indiana Jones franchise-which it argues should be seen as a benchmark in the history of this kind of narrative. Special attention is given to the treatment of the character of Indiana Jones, who is the true focal point of the narrative, and to other underlying thematic features. 


\section{INTRODUCTION}

Like some aspects of genre (Neale, 1980, p. 48) or "star system" (Chapman, 2004, pp. 74-75), seriality is a strategy based on formula repetition and has been used regularly in Hollywood narratives ever since films have been made there. This concept was especially relevant during Hollywood's first decades in the form of silent serial films (Stedman, 1971, pp. 5-6) and became the most significant feature after the emergence of television narra- tive (Hagedorn, 1995, p. 37). The origins of seriality are linked to literature, especially during the 19th century, when print media allowed the creation of new genres like the serial novel and, later, the comic strip. These serial nar- ratives are defined not only by the serial consumption of the product but also by the creation of charismatic characters. These two features of seriality have been adapted successfully into cinematic stories, from Charlie Chan to James Bond. In this respect, modern blockbusters are usually based on an expandable story, with potential for the creation of subsequent "acts." In this sense, sequels and prequels take on the form of serial episodes because "[sequels] are transitional, not conclusive. By definition, the sequel has no end" (Jess-Cooke, 2009, p. 8).

Over the years the Hollywood model has changed slightly as a conse- quence of the creation of media conglomerates (Disney, Time-Warner, etc.), which now have the capacity to control both the creation and distribution of multiple products, regardless of the media in which they are created. The blockbuster production model is now frequently associa- ted with the "brand" concept, which in a broader sense involves narratives or global stories told among different media, also known as "total enter- tainment" experiences (Grainge, 2008, p. 65). Harry Potter, Spider-Man, and Lord of the Rings are now well-known brands although, in fact, they are already macrostories. Their cross-media narrative also involves the creation of a serial story that makes use of several different media and languages.

This article proposes a new methodology for analyzing crossmedia products, based on the studies developed by Aarseth (2006), Ryan (2001, 2004, 2009), and Hernández-Pérez \& Grandío-Pérez (2011), among others. For this purpose, the parameters used in the aforementioned models have been extended and updated (Figure 1). As a case study, we have chosen the franchise built upon the well-known character of Indiana Jones (IJ), which we believe should be viewed as a benchmark in the history of serial and cross-media narrative. The saga has been running for more than 30 years, encompassing everything from movies to comics, video games, and other formats, and is now an undeniable icon of the adventure genre. The 


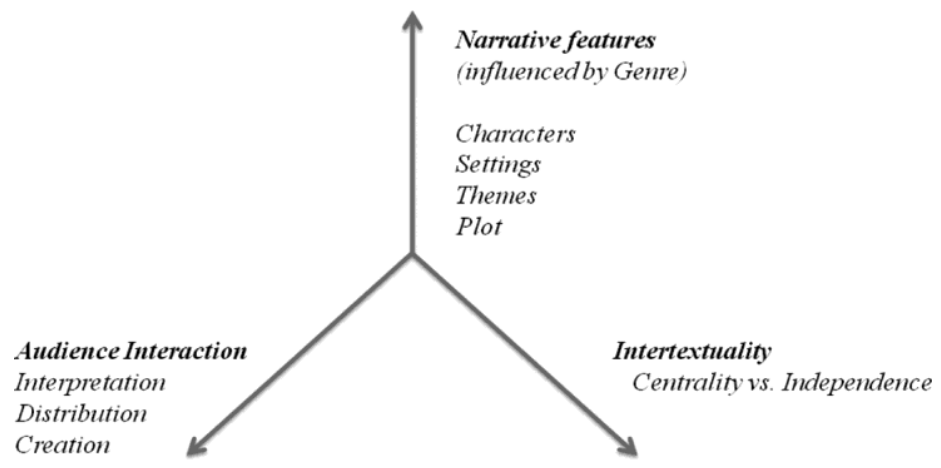

FIGURE 1 Summary of our research methodology for analyzing a cross-media narrative, based on the methodologies of Lacey (2000), Davidson (2008), Scolari (2009), and Hernández- Pérez \& Grandío (2011).

next two sections of the article introduce some concepts related to cross-media narrative as well as the history of the IJ franchise from its origins as a serial homage. After having defined the $\mathrm{IJ}$ franchise as a cross-media product, we explain our methodology through three dimensionsor axes.

The first axis specifically emphasizes narrative features (theme, plot, characters, setting). In this regard, special importance is given to the charac- ter of $I J$, the true driving force of the narrative, and to specific thematic traits. We attempt to prove that the influence of the adventure film's generic conventions over the story-medium relationship represents the main impetus behind this franchise's narrative expansion.

As the second axis, this analysis considers key components of this narra- tive architecture, such as intertextuality and [self-]reference, responsible for conferring a sense of cohesion on the macrostory as well as for optimizing itsassimilation through a genre-based reading.

Last, as the third axis of analysis, we describe the audience's role in the consumption, interpretation, and distribution of crossmedia narratives. This is intended to investigate the interaction between media and society via the aspect of the audience's role in the construction of the [cross-media] serial narrative. In modern multiplatform franchises, fan contribution has also proven to be very important in the construction of the macrostory, especially through fan fiction. Nevertheless, as we see in this article, fan contributions are not always faithful enough to canonical texts and,consequently, can damage the saga's diegetic coherence. 


\section{CROSS-MEDIA NARRATIVE: SAME CLASSIC STORIES TOLD AMONG DIVERSE MEDIA}

The term cross-media is sometimes overlooked in favor of the phrase "trans- media storytelling" (Jenkins, 2006, pp. 20-21), which refers to a narrative that is systematically dispersed across multiple media channels for the purpose of creating a unified and coordinated entertainment experience. Although both terms describe a similar phenomenon, transmedia storytelling views the inception of this dispersion across different media as a guided process. In contrast, cross-media accepts the possibility that this process may not necessarily be intentional or proactive but rather retroactive, as in the case of a franchise expanding due to its commercial success (Burn, 2004; Davidson, 2010, p. 10; Long, 2007, p. 21; Owczarski, 2009).

It is worth noting that cross-media narrative should not be confused with asimple adaptation process. Some examples include the novelization of amovie plot or the creation of an official tie-in video game based upon a sum-mer blockbuster. It is one of the processes at work in the creation of across-media story, but narrative also requires the creation of an extendedstory with primary narrative events that can ultimately be broken down into linear sequences that we define as a macrostory. In this sense, the notion of a"story," or rather the creation of a "serial story," might be

a key concept(Thompson \& Bordwell, 2007), a form of "communication where the story-line will direct the receiver from one medium to the next" (Hannele, Kangas, \& Vainikainen, 2004, p. 19). Thus, the mere creation of cross-media eventscombining languages

and formats cannot in itself be considered a form ofcross-media narration, as the latter necessarily involves the emergence of astory

that unfolds across different media and drives the user's

interpretation. This unfolding or "serial" story does not generally adopt a classic episodicstructure along a "single time line" but rather expands radially around a timeline that we call the "core of the narrative," forming autonomous timelines ofits own. This core or central narrative is also known as the "parent text" or "parent product" (Brown \& Krzywinska, 2009, p. 91), as it is the reference point for other products or texts. These products may, in turn,

become "parents" of other new stories at some point, a phenomenon known as "spin-off," particularly common in media such as television and comic books. The notion of a cohesive diegetic infrastructure is especially important to the architecture of a crossmedia narrative, while also being vital to transme-dia narratives. This may take on the rough form of a "never-ending macros-tory," in line with the video game franchise model (Brown \& Krzywinska,2009), or more complex forms more closely related to the construction of 
stand-alone narrative worlds (Jenkins, 2006, p. 113). One instance of the 
latter could be the Star Wars Expanded Universe, the umbrella under which Lucasfilm groups products in the Star Wars franchise. Indeed, this tendency toward "world building" helps explain why studies in this area traditionally have focused on science fiction products, as these are particularly well suited to self-contained content in the form of franchises and give rise to highly organic objects (Garín \& Pérez, 2009; Tulloch \& Jenkins, 1995). This genre also specializes in the generation of fan cultures (Tulloch \& Jenkins, 1995), which may contribute to the story through the production of original content.

\section{Methods, Materials, and Purpose}

Every system of symbols and every language has its limitations. This concept is widely accepted among theoreticians and implies that the selection of a given medium in large part determines the way in which a story is told, which in essence is an adaptation of McLuhan's ideas to narratology (Burn, 2004; Davidson, 2008; Ryan, 2002). We should clarify that we are using the terms "language" and "medium" as equivalents, although many new media actu-ally employ the same language or a combination of already established lan- guages (Manovich, 2002). Thus, audiovisual language is present not only in film but also in media as diverse as television episodes, interactive media, and video games. In the latter, cut-scenes (short films within the game) put the interactive nature of the game on hold in order to advance its narrative goals. In this article, we use the term "medium" to refer to the means by which the narrative product is distributed (television, film, etc.), bearing in mind that a given medium may include different languages embedded within it.

To a significant extent, the selection of a medium determines a narrative, although it is worth questioning whether this relationship between story and medium can be considered reciprocal and whether a story itself can conse- quently determine the medium in which it will take place. By viewing genre as a set of formulae for constructing an effective story that the audience can recognize (Berger, 1992, p. 44; Lacey, 2000, p. 10), we can understand the extent to which the selection of a genre can determine the product's narratological features. On the other hand, in line with Fowler's (1982,

p. 74) argument that "kinds" (a term he prefers to genres) are "marked by a complex of substantive and formal features," we see that stories that seek efficiency via genre require not only adaptation to thematic formulae but also an appropriate handling thereof in a specific medium. Consequently, genre (notwithstanding possible hybridizations, e.g., the "adventure TV serial") could very well explain how a story might determine its own medium. In keep- ing with the observations of Aarseth (2006, p. 208) based on the notion of 
32

HERNÁNDEZ-PÉREZ AND RODRÍGUEZ

popular genres described by Cawelti (1976), content transfer is determined not only by differences between media but also by gender traits, expressed 
on two levels. Thus, in the case of the IJ franchise, such differences will beconstant at the "level of cultural convention" (the possible existence of anarchetype in the character of Jones, the stereotypes and clichés, the space- time configuration of the genre), and the "level of underlying structure" (asequence of events particular to the series genre to be discussed in due course). Finally, we should clarify

that it is very difficult to access all of the materials representing the macronarrative due to the extent of the IJ franchise, parti-cularly when many of these products have not been translated into local languages or where they are confined to specific geographical context.

This is thecase with products such as the Pachinko machine, a form of entertainmentconfined almost exclusively to Japan (Indiana Jones Sankyo Fever, debutedin 2006) and the unique attractions at Disney theme parks in cities such asTokyo, Paris, and Florida. Moreover, some products, relatively inaccessibledue to limited distribution, are also recreational machines such as those developed by Media IGT (debuted in 2007) and Stern Pinball (debuted in2008). The aim of our research is not to conduct a comprehensive comparisonof all products, and, therefore, of the relevant languages, but rather to pointout that a narratological analysis facilitates access to the narrative's "deepstructure"

(Chatman, 1980, p. 21) that emerges through the franchise's macrostory. Thus, to carry out this analysis, it has been essential to consult rel-evant wikis and websites that support the fan group websites (e.g., IndyLounge, Indy Gear, The Indy Experience, and fundamentally the raider.net). Other databases, such as indianajones, wikia, and Internet Movie Database, also have served as critical resources for accessing summaries of works thatcould not be directly consulted, especially in the case of audiovisual products. Although most of these sources are global, other sources, such as indianajon-es.es (Spanish-speaking community) and indy.mamonet (in German), provide valuable information to a particular community. With respect toparticipation, websites that provide access to thousands of fandom products (fanfiction.net, theforce.net, etc.) also have been germane, although analysisis weighted toward the most relevant search engine results. Finally, officialguides available in print (Luceno, 2008; Rinzler \& Bouzereau, 2008) and documentary elements included with audiovisual editions on DVD andBlu-ray have been instrumental in this project, especially in providing information on the film saga (the franchise's core products). 
34

HERNÁNDEZ-PÉREZ AND RODRÍGUEZ

In their book about the history behind the IJ saga, Rinzler and Bouzereau(2008) pointed out several well-known sources-TV serials and comic 
books-that inspired George Lucas, executive producer of the films and spiritual father of the creation. In this sense, Raiders of the Lost Ark (Kazan- jian, Lucas, \& Spielberg, 1981), the franchise's first product and core, was originally conceived as a low-budget undertaking reminiscent of older adventure serial movies but in fact benefitted from a sizeable budget and the most sophisticated special effects of its time. These factors helped the film become one of the biggest box-office hits in history. The film and its sequels present a charismatic main character developed among different episodes, as well as other structural features that appeal to serial narratives. Through these elements, Lucas attempted to replicate serial products that had left a deep impression on him during his childhood, like Tarzan and Flash Gordon serials or Tim Tyler's Luck adventure comics (Rinzler \& Bou- zereau, 2008, pp. 16-17). More specifically, the adventure genre-also called "jungle movies"-was one of the most significant within Republic Pictures' 1950s serials. Raiders, set in the 1930s, was originally considered a nostalgic remake of these products, but it also sought to be a more realistic, updated vision of the adventure serial genre.

Thirty years later, the concept has grown into a referential multiplat- form franchise, which includes a plethora of different products ranging from video games to light novels and toys. Any viewer familiar with the IJ series (see Table 1) would undoubtedly agree that the macrostory-at least in terms of scope if not in complexity-tells a tale to rival that of other major sagas such as Star Trek (NBC, 1966-1969) and Star Wars (1977). Although the diegetic infrastructure of the Dr. Jones saga does not unfold through the creation of narrative worlds with autonomous laws (as stories framed within the science fiction and fantasy genres, such as The Matrix and The Lord of the Rings), but instead through the life of a single main character, such infrastructure manages to create a significant sense of organic unity through copious references to other characters, old friendships, past events, adventures, and facts, which are sometimes shown in media other than film. As a director and producer, George Lucas has always been fond of incorporating these elements into much of his work, and in doing so, he has opened the door to making sequels, prequels, and so on, that allow him to expand his stories and their universe beyond the limits of a single film. This way of telling stories arouses a desire to discover new stories and adventures and is intimately related to Lucas's fascination with serial characters, an aspect that he shares with Steven Spielberg, director of these films, who has always voiced his intention to create a new James Bond (Rinzler \& Bouzereau, 2008, pp. 16-17). Whether unwillingly or indeed with full knowledge of what he was doing, Lucas succeeded in creating not only lucrative enterprises but also major products themselves capable of 
36

HERNÁNDEZ-PÉREZ AND RODRÍGUEZ generating new stories. 
Downloaded by [Northeastern University] at 04:22 12 November 2014

TABLE 1

Main Narrative Products of the Indiana Jones Franchise

\begin{tabular}{|c|c|c|c|c|c|c|c|}
\hline Storyline & $\begin{array}{l}\text { Films } \\
\text { Novels }\end{array}$ & TV series & Comics & Video games & RPGs & & $\begin{array}{l}\text { Theme } \\
\text { parks } \\
\text { products }\end{array}$ \\
\hline \multicolumn{8}{|l|}{$\begin{array}{c}1899 \text { (date } \\
\text { ofbirth) }\end{array}$} \\
\hline 1909 & & $\begin{array}{l}\text { Young IJ } \\
\text { Chronicles. } \\
\text { Season I=II } \\
\text { (ABC, 1992- } \\
93 \text { ) }\end{array}$ & & & & & \\
\hline 1916-1917 & & $\begin{array}{l}\text { Young IJ } \\
\text { Chronicles } \\
\text {.Season } \\
\text { I=II(ABC, } \\
1992-93)\end{array}$ & & $\begin{array}{l}\text { The Young } \\
\text { Indiana Jones } \\
\text { Chronicles } \\
\text { (Nintendo, } \\
\text { 1992) }\end{array}$ & & & \\
\hline 1920 & & $\begin{array}{l}\text { Young IJ } \\
\text { ChroniclesTV } \\
\text { Movies=Season } \\
\text { III (Family } \\
\text { Channel, } \\
\text { 1994-96) }\end{array}$ & $\begin{array}{l}\text { Young IJ } \\
\text { Chronicles } \\
\text { (Dark Horse, } \\
\text { 1992) }\end{array}$ & $\begin{array}{l}\text { Instruments of } \\
\text { Chaos starring } \\
\text { Young IJ (Sega } \\
\text { Genesis, 1994) }\end{array}$ & & $\begin{array}{l}\text { IJ and the Peril of } \\
\text { Delphi, The } \\
\text { Dance of } \\
\text { Giants, The } \\
\text { Seven Veils, } \\
\text { The Genesis } \\
\text { Deluge, The } \\
\text { Interior World } \\
\text { (Wolfgang } \\
\text { Hohlbein; } \\
\text { 1990-93) }\end{array}$ & \\
\hline 1929-1930 & & & & & & $\begin{array}{l}\text { The Feathered } \\
\text { Snake } \\
\text { (Wolfgan } \\
\text { g } \\
\text { Hohlbein; } \\
\text { 1990-93) }\end{array}$ & \\
\hline
\end{tabular}


Continued

\begin{tabular}{|c|c|c|c|c|c|c|c|}
\hline Storyline & $\begin{array}{l}\text { Films } \\
\text { Novels }\end{array}$ & TV series & Comics & Video games & RPGs & & $\begin{array}{l}\text { Theme } \\
\text { parks } \\
\text { products }\end{array}$ \\
\hline 1935 & $\begin{array}{l}\text { IJ and The } \\
\text { Temple of } \\
\text { Doom (1984) }\end{array}$ & & $\begin{array}{l}\text { IJ and The } \\
\text { Temple of } \\
\text { Doom (Marvel } \\
\text { Comics, } \\
\text { 1986) }\end{array}$ & $\begin{array}{l}\text { IJ and the } \\
\text { Emperor's Tomb } \\
\text { (2003) IJ and } \\
\text { his } \\
\text { Desktop } \\
\text { Adventures } \\
\text { (PC, 1996) IJ and } \\
\text { The Temple of } \\
\text { Doom (1985) }\end{array}$ & $\begin{array}{l}\text { TSR-Board } \\
\text { Game (1984- } \\
\text { 85) }\end{array}$ & $\begin{array}{l}\text { IJ and The } \\
\text { Temple of } \\
\text { Doom (James } \\
\text { Khan, 1984) }\end{array}$ & $\begin{array}{l}\text { Temple of the } \\
\text { Forbidden } \\
\text { Eye } \\
\text { (Disneyland, } \\
\text { California, } \\
\\
\text { 1995); IJ et le } \\
\text { Temple du } \\
\text { Péril } \\
\text { (Disneyland } \\
\text { Paris, 1993) }\end{array}$ \\
\hline 1936 & $\begin{array}{l}\text { Raiders of the } \\
\text { Lost Ark } \\
\text { (1981) }\end{array}$ & & $\begin{array}{l}\text { Raiders of the } \\
\text { Lost Ark } \\
\text { (Marvel } \\
\text { Comics, } \\
\text { 1981) }\end{array}$ & $\begin{array}{l}\text { Raiders of the } \\
\text { Lost } \\
\text { Ark (Atari, } \\
\text { 1982) }\end{array}$ & & $\begin{array}{l}\text { Raiders of the } \\
\text { Lost Ark } \\
(1981)^{a}\end{array}$ & $\begin{array}{l}\text { IJ Epic Stunt } \\
\text { Spectacular! } \\
\text { (Disney } \\
\text { WorldFlorida, } \\
\text { 1989) }\end{array}$ \\
\hline 1938 & $\begin{array}{l}\text { IJ and The Last } \\
\text { Crusade (1989) }\end{array}$ & & $\begin{array}{l}\text { IJ and The Last } \\
\text { Crusade } \\
\text { (Marvel } \\
\text { Comics, 1989) }\end{array}$ & $\begin{array}{l}\text { Lego IJ: The } \\
\text { Original } \\
\text { Adventures } \\
\text { (2008); } \\
\text { LEGO IJ 2: } \\
\text { The Adventure } \\
\text { Continues } \\
\text { (2009); IJ and } \\
\text { the Last } \\
\text { Crusade: The } \\
\text { Graphic }\end{array}$ & $\begin{array}{l}\text { RPG Pen-and- } \\
\text { Paper and } \\
\text { Expansion } \\
\text { Sets } \\
(1994-97)^{b}\end{array}$ & $\begin{array}{l}\text { IJ and The } \\
\text { Last } \\
\text { Crusade (Rob } \\
\text { McGregor, } \\
\text { 1989) }\end{array}$ & \\
\hline
\end{tabular}


Downloaded by [Northeastern University] at 04:22 12 November 2014

Adventure

(1989) ${ }^{\text {a }}$ IJ and

the Last 
1938-1939

1939-1945

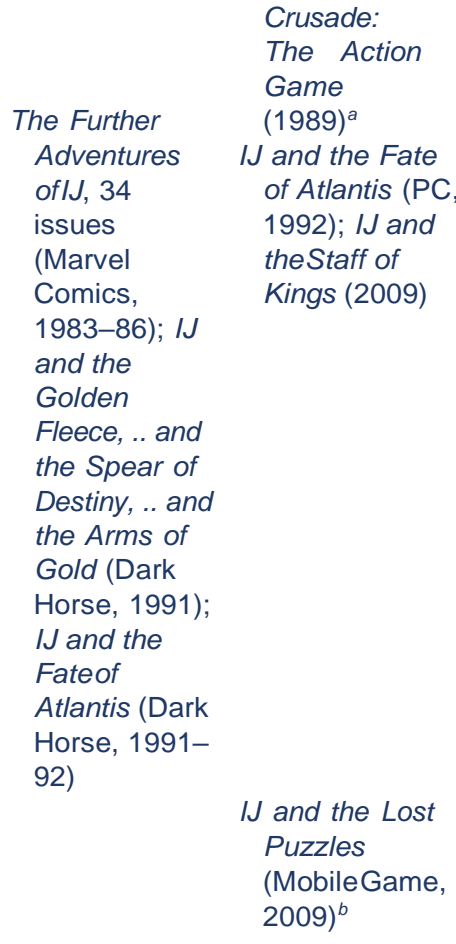

\author{
IJ and.. The \\ Shipof the \\ Gods, The \\ Gold of El \\ Dorado, The \\ Sword of \\ Genghis \\ Khan, The \\ Vanished \\ People, The \\ Secret of \\ Easter Island, \\ The Legacy of \\ Avalon, The
}


IJ Adventure: Temple of the Crystal Skull (Tokyo DisneySea, 2001) ${ }^{c}$

(Continued) 
Continued

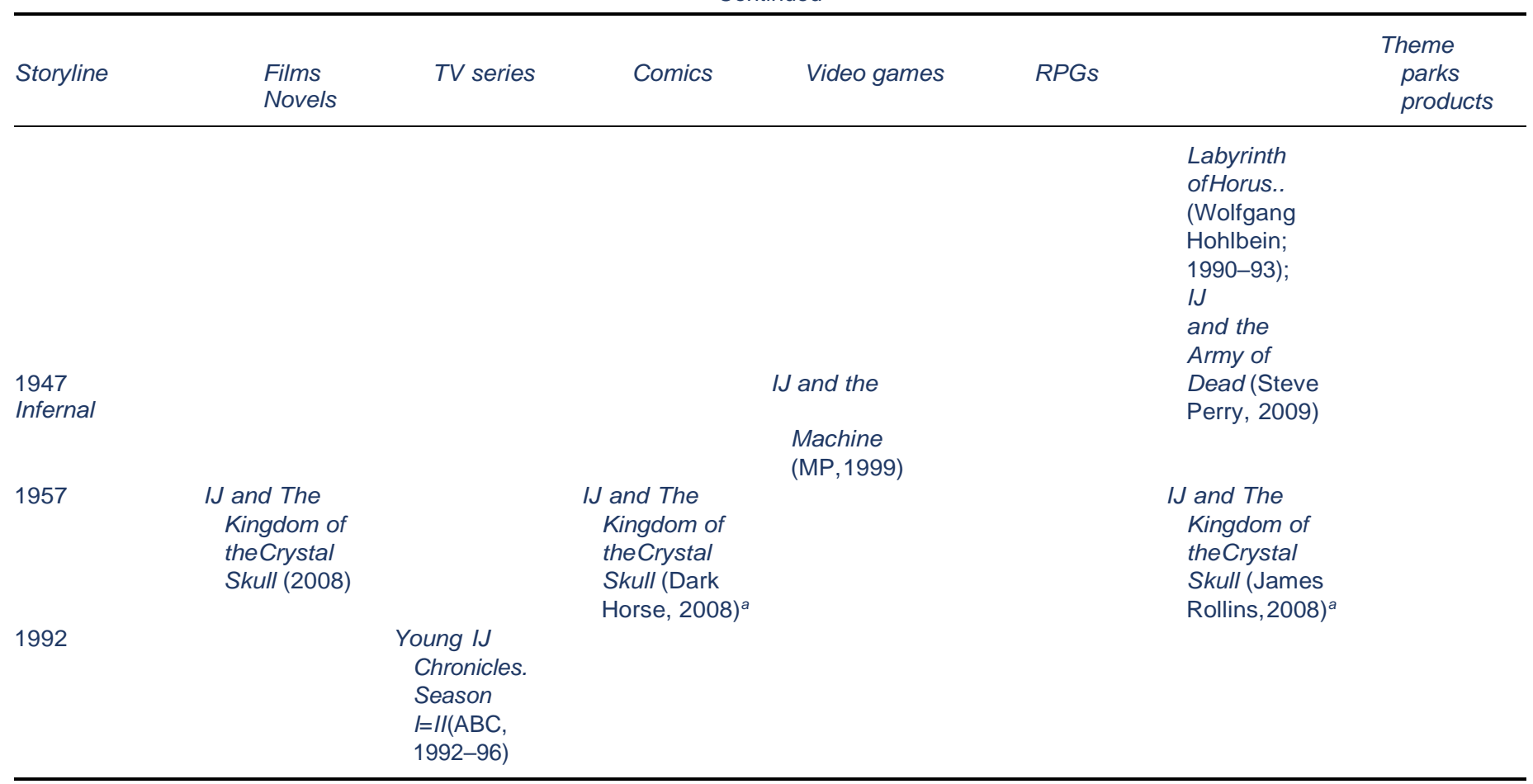

Note. Lastest update: February 4, 2013. RPG 1/4 role-playing game; IJ 1/4

andiana Jones. Adaptation of core film products.

${ }^{b}$ Without an specific temporal setting.

'Although the name is similar to the film's actually it is an independent episode. 

However, unlike science fiction serials such as Star Trek (Jenkins, 1988; Tulloch \& Jenkins, 1995), Battlestar Galactica (Hernández-Pérez \& Grandío-Pérez, 2011) and Lucas's own saga Star Wars (Jenkins, 2006,

p. 106), this sense of organic cohesion is not the key to the success of the IJ franchise but rather a product thereof, just like its narrative extension. Instead, George Lucas accelerated the process that led to the development of "transmedia consumers," or rather, users of various texts and media, in contrast to traditional users (Scolari, 2009, p. 597). By doing this, he encouraged the emergence of more engaged consumers who not only actively access stories through different media (comics, video games, role-playing games), but who also, on occasion, generate their own content (fandom). Ultimately, in this a posteriori transformation of a cinematic franchise into a macrostory unfolding across converging media, Lucas set a precedent for the Hollywood of today, where cross-media narration and the creation of blockbuster-led franchises are now, more than ever, an increasingly prevalent trend (Owczarski, 2009, p. 101; Schatz, 2009, p. 20).

\section{NARRATIVE ASPECTS OF THE CENTRAL STORY AND RELATED STORIES}

Now that the main ideas about cross-media narrative as well as the purpose of our case study have been clarified, we develop the analysis of methodology's first axis. Our perspective follows a narratological approach based on narrative features of the (macro) story, as previously noted, but also incorporates some aspects of semiotic approaches. By doing so, we hope to contribute to a discussion on "transmedia narratology" as well as the type of narrative. In keeping with the ideas of Ryan (2001), narrative must be construed as an act separate from the medium itself. Such dichotomy generally exists to some extent (not all texts are narrative), although the narrative must be defined in semantic terms. We therefore analyze narrative components through this franchise's different languages.

\section{INDIANA JONES AND OTHER CHARACTERS}

$\mathrm{IJ}$ is the driving force behind every story in the franchise and displays all of the properties and functions of a main character. Indeed, this aspect of the series is so important that the creator of the saga, George Lucas, has acknowledged that the IJ stories could not exist without IJ. He further emphasizes the relevance of the more 
38 HERNÁNDEZ-PÉREZ AND RODRÍGUEZ famous acting of the character by 
Harrison Ford. ${ }^{1}$ Moreover, in contrast to other fictional stories in which the absence of characters in some of their products does not preclude the exten- sion of a common fictional universe, there are no spin-offs or peripheral stories in the Indiana Jones franchise: the entire story revolves around the main character. This rule could be extended to all languages and media, with the single exception of the pen-and-paper role-playing games created by West End Games (1994-1997), in which the creation of characters depends on the players themselves according to a predefined set of rules.

The IJ character has aroused fascination not only among the general public but also in academic circles. Indeed, it has been studied from a variety of per- spectives, notably including those of anthropologists, who have viewed IJ as the characteristic depiction of a nostalgic Reagan-era imperialist hero (Biskind, 1990, pp. 112-149; J. Lewis, 2007, p. 78). Other scholars have been interested in examining the theories of Campbell, particularly the "hero's path," which has had a significant influence on Lucas's films (Tomasulo, 1982, pp. 331-340). It has even been suggested that the saga could be a mod-ern retelling of King Arthur stories, with IJ playing the role of a knight who embodies moral values that hearken back to another era (Aronstein, 1995). Durand's myth criticism (Balló \& Pérez, 1997, p. 91 ) is especially useful in this regard, viewing IJ as a modern version of classical acrobatic heroes who is nevertheless recognized for significant innovations. On one hand, this can be seen in the recurring appearance of "mystical elements" such as treas- uresincluding, for example, the Ark of the Covenant and the Holy Grail, among others-that serve to further the character's experience and develop- ment. On the other hand, a "journey into the past" is especially manifest in those episodes, which represent important milestones for the character. That is the case with the Jones family's significant reconciliation reference in Indiana Jones and the Last Crusade (Lucas, Marshall, \& Spielberg, 1989), where the conflict between the two Joneses paves the way for an intensely spiritual journey. This film combines family reconciliation, a topic near and dear to director Steven Spielberg (Friedman, 2006, p. 84; Morris, 2007 ,

p. 153), with well-known mystical elements of Christian iconography.

However, more than re-creating an archetype, IJ represents a new type of hero in the world of action and adventure films. This new hero's attributes and characteristics converge in the magnificent prologue to the series' first film and range from his profession to the basic traits of his personality, including his acrobatic and intellectual abilities and especially his sense of

\footnotetext{
1"Indiana Jones is Indiana Jones. Harrison Ford is Indiana Jones. If it was Mutt Williams it would be Mutt Williams and the Search for Elvis or something" (Adler,
} 
2008). This trope is taken up comically at the end of the fourth film, when Mutt, Indiana Jones's son, puts on Jones's fedora and Indy snatches it away from him so that he can wear it himself. 
humor. Furthermore, it introduces us to his wardrobe and accessories - a fedora, leather jacket, leather whip, and revolverwhich remain immutable throughout the cross-media franchise. Like many other heroes who preceded him, both on the big screen and on paper-the typical setting for serial narratives-Jones also shares another trait often bestowed upon such characters by their creators: a dual personality. When we see him lecturing on historical civilizations, he appears somewhat bumbling and wears glasses. However, his appearance and demeanor change during his adventure scenes. The Superman=Clark Kent duality seems to be the model here, although we should not rule out Zorro=Diego de la Vega, the acrobatic hero par excellence and epitome of television serial narratives. As in these films, duality is not limited to his appearance, but rather extends to a true trans- formation of personality because, as Brode (1995) noted, IJ is "a childish man who created his heroic figure so to escape the dullness of teaching at a school. Both of Indiana's personas reject one another in philosophy, creating a duality" (p. 91).

Not only does IJ combine the attributes of a classic hero-useful and dis- tinctive gear, intelligence, attractiveness, and so on-but he is also defined by his relationships with other characters. Although the cast of characters varies, the narrative functions they perform are similar. Firstly, it is worth considering IJ's relationships with family members, such as his father (Henry Jones, Sr.) and with friends, especially Marcus Brody. Some of these supporting characters perform comic roles that are founded on the contrast between them and the protagonist. Examples of this include the youth of Short Round or Mutt Williams and the cowardice or pragmatism of other comical characters like Sallah (constant presence going back to Raiders, also appearing in novels like Indiana Jones and the Philosopher's Stone and Indiana Jones and the Secret of the Sphinx).

Second, Jones's love interests are split between women who re-create the "damsel in distress" scenario so typical in the adventure genre- particularly Willie Scott in Indiana Jones and the Temple of Doom - and other depictions of more intrepid and ambitious women, such as Dr. Elsa Schneider in Indiana Jones and the Last Crusade, or Sophie Hapgood, a CIA agent in Indiana Jones and the Infernal Machine and other video games. It is interesting that Marion, the protagonist's one "true love" and the mother of his son (the young Mutt Williams), unites these two characteristics in the stories. Last, rivals in the hunt also play a key role. As a rule, these individuals-whether they are soldiers from totalitarian regimes, tomb raiders, or religious fanatics_are marked by a morally reprehensible attitude. Given these behavioral traits, they must be seen as examples of the morally flat characters that are so commonplace in 
42 HERNÁNDEZ-PÉREZ AND RODRÍGUEZ classical serial narratives. 
The choice of media also plays a pivotal role in this aspect. Novels typically provide more information about characters than movies, because the former's length and structure enable exploration of a character's back- ground and description of action. This form of narration or "telling" clearly differs from audiovisual media, which are capable of "showing" (Hutcheon, 2006, p. 33). Although worthy of discussion, such differences-audiovisual and interactive media possess many resources to convey information, not always explicitly-are absent from IJ novels. Instead, it reflects a clear tendency toward honoring and reconstructing film events, as movies are the core of narrative expansion. Thus, the "showing" mode triumphs, pervading the "telling" of the novel, and all events must be transferable to the screen, or rather, the spectator's mind. As such, the presence of villains in novels inevitably evokes the clichés established in films (Sarducci, the evil scholar of Indiana Jones and the Philosopher Stone, seems merely to constitute reuse of Belloq's character), and the same will occur, for example, with the exotic locations and pursuit scenes. Similarly, we can assume that ongoing references to film aspects will be inevitable in RPGs, a form based more on "telling" than on "showing."

\section{Setting}

Each story's setting constrains the tale, fixing it both in time and space. First, the temporal setting determines the number of stories and their relationship to the stories in the parent text or primary product. Second, an analysis of the spatial setting reveals the locations that pervade the series. In the case of IJ, the temporal and spatial settings are highly consistent.

\section{Temporal Setting}

The stories in the IJ saga are laid out along a time line that can nevertheless be viewed from two significantly different points of view. On one side, the saga tells the story of the life of Henry Walton Jones Jr., ${ }^{2}$ born in 1899 in Princeton, New Jersey, who received the nickname "Indiana" as a teenager. Jones's life begins on the cusp of the 20th century, so his life story is intertwined with some of the century's most significant historical moments and influential figures (to see the relationship between these two temporal features, see Table 1). This profoundly didactic concept is especially reflected in The Young Indiana Jones Chronicles television series as well as in the comic book and video game adaptations thereof. In these stories, the 93year-old 
44 HERNÁNDEZ-PÉREZ AND RODRÍGUEZ

Adventure"episode of The Young Indiana Jones Chronicles (ABC, 1992-1996). 
Jones looks back on the adventures of his youth and his relationships with famous individuals including Pablo Picasso (Paris, September 1908), Pancho Villa (Mexico, March 1916) and Lawrence of Arabia (Indiana Jones and the Curse of the Jackal), among others. The majority of the product cluster is situated around the 1935-1938 period on the time line. This is no mere coinci- dence, as the films, which function as core narratives, are set in this period. ${ }^{3}$

\section{Spatial Setting}

As with the temporal setting, there are two different logics at work behind the spatial setting. First, the setting is a representation of the real world inspired by 20th-century history. However, the spatial setting simultaneously includes elements typical of adventure stories or science fiction, such as magic and fantasy. The genre shapes the spatial setting and, in line with the thoughts of Sobchack (1988, p. $10)$, setting plays a key role in defining a site of danger that contrasts with the everyday life of the protagonists, through the depiction of inhospitable places or elements from a romantic past. Where danger and the past are concerned, this premise leads us to eschew terms like "exotic," which have been used extensively in defining this genre but which are inevitably colored by the relativism of the audience's experience (see novels published by Bantam Books, 1991-1999).

The spatial setting, meanwhile, shapes the story, anchoring the narrative not only in space but also through the creation of sequences linked to situa- tions characteristic of a particular cinematographic genre. In this regard, Buckland (2006) pointed out the way in which different products in the fran-chise re-create scenes from serials, as is the case, for example, with Nyoka and the Tigermen (William Witney, 1942) and the Zorro serials directed by John English and William Witney (Zorro Rides Again, 1937; Zorro's Fighting Legion, 1939), whose influence can be seen in the films' action and chase scenes (p. 143). In the IJ saga, the following typical spaces appear from the very first film in the series and recur constantly throughout the remainder of the franchise's macrostory:

- Temples, caves, and passageways, along with inhospitable settings like jun- gles or exotic lands, fundamentally represent the forbidden and therefore the "site of danger" previously mentioned. These are probably the ele- ments that most connect Jones to the colonial stories of H. Rider Haggard and Rudyard Kipling. From Africa and the Middle East (Raiders) to Asia 
46 HERNÁNDEZ-PÉREZ AND RODRÍGUEZ Machine). 
(Indiana Jones Thunder in Orient; Indiana Jones and the Staff of Kings; Indiana Jones and the Temple of Doom) by way of South America (Indiana Jones and the Kingdom of the Crystal Skull; Indiana Jones and the Arms of Gold), these "exotic" film settings bring to mind a whole series of texts invarious media.

- The university is a key location for setting up the character's duality. As such, universities and libraries reinforce the intellectual yet passive side of Dr. Henry Jones, just as the inhospitable settings of the jungle or desert characterize Indiana. In Indiana Jones and the Kingdom of the Crystal Skull, the university-in conjunction with other urban areas-provides a historical context that evokes the social issues surrounding youth and education in the 1950s.

\section{Plots}

A plot is a series of narrative events that, in the case of serial products, can be split into independent episodes. In the franchise's core (the four films), the plots chiefly adopt the typical logic of an adventure story. These types of stor-ies are part of a well-established genre and adhere to a series of specific formu- lae. As such, the hunt always contains the same phases, in line with what Ballo and Pérez (1997, p. 15) have referred to as a "treasure hunt," one that, in this case, takes on a mystical quality. The sequence usually consists of a "prelimi- nary assignment, a long and risky journey, duels, help from an unexpected source, an eventful flight, and a victorious return, while never precluding the possibility of a new adventure." 4 In addition, each chapter of the saga pre- sents its own characteristic innovation with regard to this type of story, with the hero acquiring new knowledge of a moral or spiritual nature, as just noted. This can be summed up in IJ's well-known assertion that "knowledge was their [the Ugha's] treasure" (Indiana Jones and the Kingdom of the Crystal Skull).

From a formal point of view, the IJ films exhibit a trait typical of classic serial narratives, which are based on a continuous series of arcs leading up to a cliffhanger. This aspect, explicitly stated by Lucas and Spielberg themselves (Rinzler \& Bouzereau, 2008, p. 241), owes its origin to the serial nature of the products upon which the IJ franchise is inspired. This trend can be distinguished from other genres, like modern melodrama, which instead exhibits a "graduated moral structure" (Smith, 1995, pp. 201-214). These sources of inspiration, like James Bond, Doc Savage, Zorro, and other serial adventures, present another notable characteristic: They apparently lack "character arcs." In other words, their characters do not develop as a result 
48 HERNÁNDEZ-PÉREZ AND RODRÍGUEZ ${ }^{4}$ Our translation. 
of the narrative events; characters are fundamentally similar from one episode to the next. The case of Dr. Jones is no different. Although we sometimes see a sharp conflict between seeking personal satisfaction (the quest for "fortune and glory" in Indiana Jones and the Temple of Doom) and social good, Jones generally displays untarnished moral integrity when forced to confront this dilemma ("This should be in a museum!").

Other formal characteristics of serial narratives, which are as rooted in the genre as the themes explored and certain character traits, are maintained across all media in the franchise. The IJ video games-whether they are official movie tie-ins or new storiesexhibit a combination of elements of representation (narrative) and simulation, with the approach to analyzing this mix at the heart of serious debates in recent years (Frasca, 2003; Juul, 2001). According to Ryan (2009) we cannot ignore the existence of nonnarrative games (or "abstract" games) like Indiana Jones and the Lost Puzzles. Nevertheless, most of the franchise video games are better suited for the author's category of "Narrative Games" because the story comple- ments the game-play experience (Ryan, 2009, p. 45). Moreover, because of the strong association that we identified between the character and the story (complemented here by gameplay experience), most video games assume a narrative based on external and explorational interactivity (Ryan, 2001). In other words, point of view is usually the third-person muppet, and the user is unable to control the order of events, simply following a preset script. In fact, it is so significant that there are no IJ Playable Stories or free-play frameworks except those provided by toys and accessories like whips, guns, or hats. In a movie tie-in video game, the player's main pleasure lies in faithfully re-creating adventures, not just following the scripts but being the "real" Indy. That might be the goal of $3 D$ realistic reconstruction of Harrison Ford in video games like Indiana Jones and The Staff of the Kings. This is because the saga's video games replicate the stories in a similar way to that of pen-and-paper role-playing and board games. Both forms share a fundamental feature-the "creation of virtual worlds" (Dormans, 2006) - although in the franchise's products the depiction and replication of cinema- tographic elements are more important than the simulation aspect. Accord- ingly, the video games constantly recreate the films, even in the case of stand-alone episodes like Indiana Jones and the Fate of Atlantis or Indiana Jones and the Staff of Kings in which the aesthetic and narrative aspects of the video games map perfectly onto those of the serial products.

\section{Themes}

All stories contain a key theme that sums up the narrative. This 
50

HERNÁNDEZ-PÉREZ AND RODRÍGUEZ

identifying element is of utmost importance in expanded stories, whereby however much 
the setting, characters, and plotlines change, the narrative remains recogniz- able. In the case of the IJ franchise, this key concept can be boiled down to an endorsement of the notion of "the value of knowledge" (Ferreras Rodr'ıguez \& Hernández-Pérez, 2011, p. 177). In this regard, IJ can be seen as a hero who continues to learn throughout his life. The pursuit of knowledge thus becomes the main narrative device underpinning the films, video games, and comics in the franchise. Knowledge is the main commodity exchanged, linking together the main character (Jones) and other characters through different instances of the "narrative program" (Le Groupe d'Entrevernes, 1979). The main character is actively helped on his way by the efforts of sev- eral supporting characters, enabling him to achieve his goals. This explains why many of these secondary characters, such as Marion, Marcus, and even the young Mutt Williams, are also archaeologists. These sympathetic charac- ters are, nevertheless, counterbalanced by other figures, occasionally mytho- logical and fantastical characters, such as the Knight Templar and the aliens in Indiana Jones and the Kingdom of the Crystal Skull, who performa punitive-or rewarding-function.

This borrowed knowledge, often obtained from books, maps, or directly from other supporting characters, is not necessarily at odds with the role of deduction. Deductive skills are vital in order to fill in and interpret gaps in the maps, and to overcome any obstacles to the quest for learning. Some examples of this issue include the library scene of Indiana Jones and the Last Crusade movie and graphic adventure and comics like Indiana Jones and the Fate of Atlantis. Coming back to the most popular examples from the films, knowledge is not simply material (e.g., the location of the Well of Souls) but also spiritual ("Only the penitent man shall pass"). Jones's adversaries, mean- while, whether rival archaeologists such as Belloq and Donovan, or soldiers from totalitarian regimes, rely on "superficial knowledge," a mistake that eventually leads to their downfall (Kerr, 2008, p. 16). In The Young Indiana Jones Chronicles television series, meanwhile, the plots are crafted in such a way as to advance the didactic angle just mentioned. Although the protagon- ist of the stories is a young Jones at different times in his life, the story arcs aim to narrate important events in 20th-century history. As Lucas himself sta- ted, "The show is designed to spark the imagination and curiosity of students and just acquaint them, on the barest level, with these figures" (Weinraub, 1992). However, this approach, which more closely resembles that of histori- cal novels than proper historicism, is prone to reproducing certain errors, such as "decontextualisation and simplification" (Hueso, 1991, p. 3).

Of interest, this quest for knowledge underlying the IJ macrostory is also in evidence in the backstory of the saga's creator. On numerous occasions, Lucas has voiced his interest in education, which he 
52 HERNÁNDEZ-PÉREZ AND RODRÍGUEZ

considers "the foundation of our democracy, the stepping-stones for our youth to reach their full 
potential" (Edutopia, 2005). One example of this personal motivation comes in the form of the George Lucas Educational Foundation, set up in 1991, which aims to compile documents and resources to support the incorporation of new technologies in schools.

\section{INTERTEXTUALITY AND SELF-REFERENCE IN THE INDIANA JONES SAGA: CENTRAL AND RELATED STORIES}

Intertextuality and centrality are essential features of any cross-media narra- tive. Even when it can be difficult to identify the central product of a series, it nevertheless can be concluded that there must be a product that serves as the parent text to the others, fulfilling the function of the ultimate reference point. In the case of cross-media products developed retroactively, the afore- mentioned reference point also tends to be the origin of the franchise. Despite the differences among IJ media, it can be argued that the films-made between 1981 and 2008-serve as the core media or parent text(s) in this fic- tional universe. There is no doubt that the most frequently referenced film of the series is Raiders of the Lost Ark. ${ }^{5}$ In terms of the internal dynamics, which are delimited by the saga's extensive macrostory, intertextuality benefits from the cohesion of a narrative, and this in turn enriches the coherence of its diegetic structure through a process of self-referentiality. This is most commonly expressed in the franchise through the films themselves, although references to the movies also abound in video games and other related pro- ducts, especially comics (Indiana Jones and the Arms of Gold). In the fourth film, self-referentiality can be seen to further the creation and heighten the cohesion of a self-contained narrative universe when the main character refers in his dialogue to events from the television series (I Rode with Pancho Villa) and other films (They Weren't You, Honey). Where other texts are con- cerned (especially comics and video games), the Jones franchise contains numerous intertextual references to serials and B-movies. ${ }^{6}$ The influences of the adventure and science fiction film genres (Indiana Jones and the Kingdom of the Crystal Skull; Further Adventures of Indiana Jones, i.19;

${ }^{5}$ All of the films include visual allusions to the Ark or to events from the first film, with the sole exception of $I J$ and The Temple of Doom, which is set chronologically before Raiders. This picture, however, contains references to character traits in the adult Indy (such as his fear of snakes) that have been previously established.

${ }^{6}$ Comics have had a major influence on Lucas. These include Carl Barks's Disney series about Scrooge McDuck, to which the director acknowledges his debt in the preface to the author's tribute book, Uncle Scrooge McDuck: His Life and Times (Lucas, 1987). Meanwhile, Buckland (2006, p. 130), citing Calebrese (1992, pp. 173179), cites up to 350 references to B-movie serials, although he fails to supply an 
54 HERNÁNDEZ-PÉREZ AND RODRÍGUEZ exhaustive list. 
Indiana Jones and the Infernal Machine), and, marginally, horror (Indiana Jones and the Iron Phoenix; Indiana Jones and the Army of Dead), seem to be linked to this practice of intertextuality, which also includes references to the Spaghetti Western and other serial narratives, especially those from comic and TV (Rinzler \& Bouzereau, 2008, p. 179).

Finally, it is worth noting the franchise's considerable influence on other entertainment products since its creation, serving as a model for a number of other works. What these have in common with the IJ franchise is the attempt to update the adventure film and other subgenres such as "treasure-hunt movies," couching them in a more realistic tone and portray- ing characters who are clearly inspired by the famous archaeologist. The most successful such stories have even led to the creation of new franchises, such as The Mummy (19992008) and National Treasure (2004-2007), as well as a number of less successful products. Video games starring treasure hunters, starting with Pitfall! (1982) and, more recently, products like Uncharted (2008-2011) and Tomb Raider (1996-2011) bear traces of its influence. These sagas share the spatial setting typical of adventure films, and they even build their own world based on the same idea of the main character development. Nevertheless, they are markedly different in the coding of their characters, which are set up as action heroes who generally lack the moral bent that characterizes the hero of Lucas's franchise.

\section{DISTRIBUTION AND CREATION: THE ROLE OF AUDIENCES IN EXPANDING CROSS-MEDIA NARRATIVES}

Another way of studying a cross-media product is by analyzing its audiences, that is, the role they play in the franchise's narrative expansion. Fan studies point to a significant transformation in these groups from the concept of mass consumer to a more active group of consumers. From this perspective, fans form collaborative subcultures based on strategies opposed to the domi- nant norms and a constant readiness to negotiate meanings (Fiske, 1992, pp. 35-38; Jenkins, 1992, p. 35). In this sense, new technologies, especially computer software, have allowed the emergence of more engaged consumers who also have access to a greater number of texts. These technologies and the "complex semiotic device" they offer may be the leading cause of the evolution from "single-text" consumers into "transmedia" ones (Scolari, 2009). Now, these new audiences can take on a variety of roles, depending on the nature of their relationship or level of engagement with the product: 
56 HERNÁNDEZ-PÉREZ AND RODRÍGUEZ through avariety of online systems (P2P, DDL, etc.). In addition, as is the case 
with all types of products, users often set up and participate in forums dedicated to producing subtitles (fansubs for movies and video games) and translations. The purpose of these partnerships is to share the fran- chise's products among fans given that such products often target local markets (e.g., IJ pen-and-paper RPGs and board games).

2. As interpreters of entire texts: Fans come together in communities, chat on forums and social networks, and write their own blogs offering various keys for interpreting the macrostory. Owing to their solidity and complexity, "wikis" or thematic encyclopedias are probably the most important subproducts.

3. As creators of new stories: The IJ franchise has generated a large amount of cultural products wholly developed by fans. These fan fictions involve unofficial extensions of the macrostory, which do not seek to conceal their amateur nature. In the case of IJ, most of these contributions allude to the main products in the saga, namely, the films made by the Spielberg- Lucas duo. As such, although they do not consist in all cases of audiovi- sual products, it can be argued that a "cinematographic" essence is their distinguishing characteristic, one that is apparent even in nonaudiovisual media such as novels and comics. In the audiovisual medium, the most common type of stories come in the form of tribute pieces, principally short films, due to fans' lack of resources. There are, however, some pecu- liar exceptions, such as the independent feature-length movie Raiders of the Lost Ark: The Adaptation (1989). This production, made on video, comprises a shot-by-shot reconstruction of the original film, produced over a 6-year span. Creations from the fan community also occur in the world of gaming. These products include brandnew (open source) games and "mods," which are modified versions that take advantage of the engine of original games. These modifications allow players to enjoy new locations and features, or may enhance official products through patches or even translations of texts.

Fan contributions do not, however, always result in a coherent expansion of the IJ narrative. This is the case, for example, of the mod in which Indy becomes the star of a first-person shooter, using the engine from Half-Life 2, or embodying a British Colonial Empire hero-despite his American nationality-in Age of Empires. Canonical texts can be undermined by the introduction of massive new authors into the franchise. Conversely, there can be little doubt that the fan phenomenon and its cultural manifestations do not represent all audiences but rather only those that are the "most visible and identifiable" (L. A. Lewis, 1992, p. 2). Nevertheless, the roles played by these new and more engaged audiences as "textual 
58 HERNÁNDEZ-PÉREZ AND RODRÍGUEZ poachers" (Jenkins, 1992), disseminating a product and heightening its accessibility, have an 
impact that extends beyond their immediate environment to the rest of the audience. For example, many single-text consumers (whether such text comes in the form of a comic, video game, or film) come into contact with other texts through P2P file-sharing systems. These consumers frequently end up becoming multitext or transmedia consumers as a result of infor- mation available online. Along the same lines, fictional encyclopedias and Wikipedias are excellent tools for encouraging people to consume other cross-media products. Moreover, it is clear that the big Hollywood studios have introduced wider audiences to texts traditionally linked to more discur-sive and creative communities (fans). This appropriation is evident in the example of successful franchises based on comics (Spider-Man), novels (Harry Potter, The Lord of the Rings), and video games (Resident Evil), a phenomenon that is making it increasingly difficult to draw the line between fans and general audiences. The entertainment industry is justified in adopt- ing these texts as inspiration for their franchises. First, some media (video games, comics, RPGs, etc.) share the same target audience with blockbusters: teenagers (Schatz, 2009, p. 34), who are expected to welcome these products to the same extent. Second, as noted earlier, narrative expansion encourages other franchise products, winning over new fans, who migrate from one medium to another. Finally, another notable influence from this group of audiences is related to the creation of texts in which intertextuality is the most characteristic feature. Franchises and their textual materials increasingly come to resemble those of fans, as both sets are "extensive, multi-authored 'works in progress' "' (Stein \& Busse, 2009, p. 193). This is one feature, however, that the Jones franchise has not sought to exploit as a marketing tool, unlike other franchises more involved with their fans. This is the case with the TV series Heroes (2006) and the relaunch of the Battlestar Galactica (2003) franchise, both of which have encouraged fandom as a vehicle for promoting their stories.

\section{CONCLUSIONS}

A study of the IJ franchise has shown how it is possible for a narrative to be expanded through different media while maintaining a sense of organic unity and coherence throughout. In this respect, the saga's macrostory has served as a pertinent example of cross-media narrative through the three proposed axes of analysis: narrative features, intertextuality, and the role of different kind of audiences. Thus, the IJ franchise can be compared to other sci-fi macrostories like Star Wars or Star Trek, but it also exhibits relevant differ- ences. First, the story focuses on the development of a main character rather than "building a world." Second, in addition to overseeing its 
60 HERNÁNDEZ-PÉREZ AND RODRÍGUEZ cross-media 
dimension, the creator, George Lucas, was also responsible for injecting a highly personal idea into the franchise, namely, the value related to the acqui- sition of knowledge. However, although the franchise has enough traits in common with serial narratives as to make it well suited for the unfolding of linked stories, all evidence points to the fact that the expansion of the story was due primarily to commercial success. Therefore, the story is retroactive in nature. In other words, the saga was not conceived in transmedia terms from the outset but rather evolved into a transmedia product that must be considered as a form of retroactive cross-media. This serial narrative archi- tecture also set the franchise apart from other film sagas like The Lord of the Rings (2001-2003) and The Godfather (1972-1990), which embody an Aristotelian development in their respective stories through sequels, conse- quently forming a larger narrative unit (JessCooke, 2009, p. 101). At the same time, the IJ franchise has more in common with other serial narratives like Batman and the James Bond series, as they are based on a character development through a long serial, though not necessarily in chronological order. Another feature that links the franchise with these serials might be their complex relationship networks, similar to soap operas (Allen, 1995,

p. 18). Accordingly, though these macrostories may present an author component (ethos) in their different texts, this component must be always driven by a figure like the editor-in-chief of the comicbook industry. Hence, we do not claim that the figure of George Lucas represents a transmedia author but rather, in line with some authors, resembles a relevant agent of these new industries (Chapman, 2004, p. 143; Jenkins, 2006, p. 106). Ultimately, the IJ saga should be recognized as occupying a prominent position in the transition between franchises and transmedia storytelling.

Another relevant feature in the IJ franchise in contrast with other macros- tories is its relationship to the adventure genre, which seems to transfer elements from both "cultural convention" and "underlying structure" (Aarseth, 2006; Cawelti, 1976). Although the key narrative aspects, such as the setting; themes; plots; and, on certain occasions, the characters, may be affected by the choice of the narrative medium, the influence of genre is evident throughout the different media. Genre, understood as "cultural con- vention," permeates the IJ saga's manifestations across different media, all of which in one way or another, re-create traits from adventure narratives and, on the odd occasion, from the science-fiction genre. From a formal point of view ("underlying structures"), the adventure film genre has a marked influ- ence on the central products in the franchise, particularly in the re-creation of television serials (Buckland, 2006, pp. 130-132). This influence is transferred from the cinematic medium into the ancillary products due to the embedding of other languages, especially audiovisual ones into new interactive media 
62 HERNÁNDEZ-PÉREZ AND RODRÍGUEZ

(Bolter \& Grusin, 1999; Manovich, 2002), principally in the case of cutscenes 
in video games. Conversely, cinematographic products-the core of the franchise-seem to have an impact on various other narratives, such as comics and role-playing games, with plots that emulate the franchise and that replicate the narrative structures and specific setting of the adventure film genre. As such, although the presence of these generic formulae shapes cross-media narrative, it is equally true, as noted by Neale (1995, p. 172), that generic images are constructed through the interaction of media in "intertex- tual relay," an element that is particularly prevalent in film marketing campaigns. This line of inquiry could be a fertile path to follow in order to determine the influence of cross-media narrative in the construction of gen- eric images, a framework similar to that of other researchers (Gray, 2010) who examine the synergy in advertising promos, peripheral products like toys, and other paratexts frequently appearing in franchise storytelling.

Last, there are some cross-media influences we have not been able to address within the scope of this article, as they are linked to the code of each media rather than the influence from the genre or the macrostory's narrative features. They include, for example, the aesthetic implications of incorporat-ing the language of video games into the cinematographic narrative. Lucas's franchise once again proves itself to be particularly innovative in this respect, representing the first of its kind to develop similar subjective experiences in both theme park rides and films, while promoting aesthetic hybridization between highly different products. The frenetic style of Indiana Jones and the Temple of Doom could well be seen as a precedent for this postclassical cinema, so roundly denounced "for such antiquated qualities as character development and human drama, as well as their spectacular CG effects and action sequences, which are now the sine qua non of blockbuster hit films" (Schatz, 2009, p. 32).

In short, this article has highlighted the most important aspects of the cross-media phenomenon among film-driven franchises. At the same time, a new methodology for the analysis of these macrostories based on multiple approaches (narrative theory, semiotics, fans studies, etc.) has been tested on one of the most significant franchises of the last decades. We hope these ideas prove to be useful in future research and can shed some light on the origins and development of both cross-media narratives and other serial products.

\section{REFERENCES}

Aarseth, E. (2006). The culture and business of cross-media productions. Popular Communi- cation: The International Journal of Media and Culture, 4, 203-211.

Adler, S. (2008). 'Indiana Jones 5' won't center on Shia LaBeouf, insists George Lucas. MTV Movies Blog. Retrieved from http://moviesblog.mtv.com/2008/08/05/exclusive-indiana- jones-5-wont-centeron- 
64 HERNÁNDEZ-PÉREZ AND RODRÍGUEZ

shia-labeouf-george-lucas-insists/ 
Allen, R. C. (1995). Introduction. In R. C. Allen (Ed.), To be continued... Soap operas aroundthe world (pp. 1-26). London, UK: Routledge.

Aronstein, S. (1995). "Not exactly a knight": Arthurian narrative and recuperative politics inthe "Indiana Jones" trilogy. Cinema Journal, 34(4), 3-30.

Balló, J., \& Pérez, X. (1997). La semilla inmortal: los argumentos universales en el cine [The inmortal seed: universal plots in the cinema]. Barcelona, Spain: Anagrama.

Berger, A. A. (1992). Popular culture genre: Theories and texts. Newbury Park, CA: SagePublications.

Biskind, P. (1990). Blockbuster: The last crusade. In M. C. Miller (Ed.), Seeing through movies

(pp. 112-149). New York, NY: Pantheon.

Bolter, J. D., \& Grusin, R. (1999). Remediation. Understanding new media. Cambridge, MA:MIT Press.

Brode, D. (1995). The films of Steven Spielberg. New York, NY: Carol Pub. Group.

Brown, D., \& Krzywinska, T. (2009). Movie-games and game-movies: Towards an aesthetics of transmediality. In W. Buckland (Ed.), Film theory and contemporary Hollywood movies (pp. 86-102). New York, NY: Routledge.

Buckland, W. (2006). Directed by Steven Spielberg: Poetics of the contemporary Hollywood blockbuster. London, UK: Continuum.

Burn, A. (2004). Potter-literacy: From book to game and back again; literature, film, game and cross-media literacy. Papers: Explorations into Children's Literature, 14(2), 5-17.

Calebrese, O. (1992). Neo-Baroque: A sign of the times. Princeton, NJ: Princeton University Press.

Cawelti, J. G. (1976). Adventure, mystery, and romance: Formula stories as art and popular culture. Chicago, IL: University of Chicago Press.

Chapman, J. (2004). Cinemas of the world: Film and society from 1895 to the present. London, UK: Reaktion Books.

Chatman, S. (1980). Story and discourse: Narrative structure in fiction and film. New York, NY:Cornell University Press.

Davidson, A. (2008). Stories in between: Narratives and mediums@ play.Pittsburgh, PA: ETC Press.

Davidson, D. (2010). Cross-media communications: An introduction to the art of creating integrated media experiences. Lulu Enterprises Inc.

Dormans, J. (2006). On the role of the die: A brief ludologic study of pen-and-paper roleplaying games and their rules. Game Studies, The International Journal of Computer

Game Research, 6(1).

Edutopia. (2005). A word from George Lucas: Edutopia's role in education. Retrieved from http://www.edutopia.org/word-from-george-lucas-edutopias-role-in-education

Ferreras Rodríguez, J. G., \& Hernández-Pérez, M. (2011). Pensar el Cine Blockbuster: El Rol de la Educación y el Conocimiento en Indiana Jones y el Reino de la Calavera de Cristal [Thinking about blockbusters: The role of education and knowledge in Indiana Jones and the Kingdom of the Crystal Skull]. Comunicación. Revista Internacional de Comunicación Audiovisual, Publicidad y Estudios Culturales, 1, 175-188.

Fiske, J. (1992). The cultural economy of fandom. In L. A. Lewis (Ed.), The adoring audience: Fan culture and popular media (pp. 30-49). London, UK: Routledge.

Fowler, A. (1982). Kinds of literature: An introduction to the theory of genres and modes. Cambridge, MA: Harvard University Press.

Frasca, G. (2003). Simulation versus narrative. In M. J. P. Wolf, \& B. Perron (Eds.), The video game theory reader (pp. 221-235). New York, NY: Routledge.

Friedman, L. D. (2006). Citizen Spielberg. Champaign: University of Illinois Press.

Garín, M., \& Pérez, O. (2009). Entre mundos e historias: Ciencia ficción y experiencia de juego [Between worlds and stories: Science fiction and the gaming experience]. Formats: Revista 
de comunicacio' audiovisual, (05). Retrieved from http://www.upf.edu/materials/depeca/formats/art_dos6_esp.htm

Grainge, P. (2008). Brand Hollywood: Selling entertainment in a global media age. New York, NY: Routledge.

Gray, J. A. (2010). Show sold separately: Promos, spoilers, and other media paratexts. NewYork: New York University Press.

Groupe d'Entrevernes. (1979). Analyse sémiotique des textes: Introduction, théorie, practique. Lyon, France: Presses Universitaires de Lyon.

Hagedorn, R. (1995). Doubtless to be continued: A brief history of serial narrative. In R.

C. Allen(Ed.), To be continued... Soap operas around the world (pp. 27-48). London,

UK: Routledge. Hannele, A., Kangas, S., \& Vainikainen, S. (2004). MGAIN Project:

Three views on mobile crossmedia entertainment [TTE4-2004-17]. VTT Information

Technology, Research Report.Retrieved from

http://www.vtt.fi/tte/rd/multiplemedia/show/crossmedia_entertainment.pdf

Hernández-Pérez, M., \& Grandío-Pérez, M. d. M. (2011). Narrativa crossmedia en el discurso televisivo de Ciencia Ficción. Estudio de Battlestar Galactica (2003-

2010) [Cross-media

narrative in SCI-FI television discourse. The case of Battlestar Galactica (2003-2010)]. Á rea

Abierta, 28, 4-28.

Hueso, Á. L. (1991). Planteamientos historiográficos en el cine histórico

[Historiographic approaches on historical cinema]. Filmhistoria Online, 13-24.

Hutcheon, L. (2006). A theory of adaptation. New York, NY: Routledge.

Jenkins, H., III. (1988). Star Trek rerun, reread, rewritten: Fan writing as textual poaching.

Critical Studies in Media Communication, 5, 85-107.

Jenkins, H. (1992). Textual poachers: television fans \& participatory culture. New York, NY:Routledge.

Jenkins, H. (2006). Convergence culture: Where old and new media collide. New York: New YorkUniversity Press.

Jess-Cooke, C. (2009). Film sequels: Theory and practice from Hollywood to

Bollywood.Edinburgh, UK: Edinburgh University Press.

Juul, J. (2001). Games telling stories? A brief note on games and narratives. Game Studies, 1, $1-12$.

Kazanjian, H., \& Lucas, G. (Producers), \& Spielberg, S. (Director). (1981). Raiders of the lostark [Motion picture]. United States: Paramount.

Kerr, J. F. (2008). Indiana Jones and the readers of the lost art: Making the

Kingdom of theCrystal Skull educational. Screen Education, 51, 14-20.

Lacey, N. (2000). Narrative and genre: Key concepts in media studies. New York: St.

Martin's. Le Groupe d'Entrevernes (1979). Analyse sémiotique des textes: Introduction, théorie, practique [Semiotic analysis of texts: Introduction, theory, practice]. Lyon,

Universitaires de Lyon.

France: Presses

Lewis, J. (2007). The perfect money machine(s). George Lucas, Steven Spielberg and

Auterismin the New Hollywood. In J. Lewis \& E. L. Smoodin (Eds.), Looking past the screen: case studies in American film history and method (pp. 61-76). Durham, NC:

Duke University Press. Lewis, L. A. (1992). The adoring audience: Fan culture and popular media. London, UK: Routledge.Long, G. A. (2007). Transmedia storytelling: Business, aesthetics and production at the Jim

Henson Company. Cambridge, MA: MIT, Department of Comparative Media

Studies. Lucas, G. (1987). Prologue. In E. Summer (Ed.), Uncle Scrooge McDuck: His life and times by

Carl Barks (pp. 2-8). Berkeley, CA: Celestial Arts.

Lucas, G., \& Marshall, F. (Producers), \& Spielberg, S. (Director). (1989). Indiana Jones and thelast crusade [Motion picture]. United States: Paramount.

Luceno, J. (2008). Indiana Jones: The ultimate guide. New York, NY: DK 
Children. Manovich, L. (2002). The language of new media. Cambridge, MA: MIT Press.

Morris, N. (2007). The cinema of Steven Spielberg: empire of light. New York, NY: Wallflower Press. 
Neale, S. (1980). Genre. London, UK: British Film Institute.

Neale, S. (1995). Questions of genre. In B. K. Grant (Ed.), Film genre: Theory and criticism

(pp. 159-183). London, UK: The Scarecrow Press.

Owczarski, K. A. (2009). "Batman," Time Warner, and franchise filmmaking in the conglomerate era. Austin: The University of Texas Press.

Rinzler, J. W., \& Bouzereau, L. (2008). The complete making of Indiana Jones: The definitive story behind all four films. London, UK: Ebury.

Ryan, M.-L. (2001). Beyond myth and metaphor. The case of narrative in digital media. Game Studies, 1(1). Retrieved from http://www.gamestudies.org/0101/ryan/

Ryan, M. L. (2004). Introduction. In M. L. Ryan (Ed.), Narrative across media: The languages of storytelling (pp. 1-40). Lincoln: University of Nebraska Press.

Ryan, M. L. (2009). From narrative games to playable stories: Toward a poetics of interactive narrative. Storyworlds: A Journal of Narrative Studies, 1, 43-59.

Schatz, T. (2009). New Hollywood, new millennium. In W. Buckland (Ed.), Film theory and contemporary Hollywood movies (pp. 19-46). New York, NY: Routledge.

Scolari, C. A. (2009). Transmedia storytelling. Implicit consumers, narrative worlds, and branding in contemporary media production. International Journal of Communication, 3, 586-606.

Smith, M. (1995). Engaging characters: Fiction, emotion, and the cinema. Oxford, UK: OxfordUniversity Press.

Sobchack, V. (1988). Science fiction. In W. D. Gehring (Ed.), Handbook of American film genres(pp. 229-247). New York, NY: Greenwood Press.

Stedman, R. W. (1971). The serials: Suspense and drama by installment. Norman: University ofOklahoma Press.

Stein, L., \& Busse, K. (2009). Limit play: Fan authorship between source text, intertext, andcontext. Popular Communication: The International Journal of Media and Culture, 7, 192-207. Thompson, K., \& Bordwell, D. (2007, May 20). Live with it! There'll always be movie sequels. Good thing, too. David Bordwell's website on cinema.

Observation on film art. Retrieved from

http://www.davidbordwell.net/blog/2007/05/20/live-with-it-therell-always-be-moviesequelsgood-thing-too/

Tomasulo, F. P. (1982). Mr. Jones goes to Washington myth and religion in Raiders of the LostArk. Quarterly Review of Film and Video, 7, 331-340.

Tulloch, J., \& Jenkins, H. (1995). Science fiction audiences: Watching Doctor Who and StarTrek. New York, NY: Routledge.

Weinraub, B. (1992, January 27). George Lucas on issues, ideas and Indiana Jones. The NewYork Times. Retrieved from http://www.nytimes.com/ 